\title{
Hygiene Behavior in Middle School Students in Ankara, Turkey
}

\author{
Sidika Bulduk ${ }^{1}$, Emre Ozgur Bulduk ${ }^{2}$ \\ ${ }^{1}$ Gazi University, Faculty of Health Sciences, Department of Nutrition and Dietetics, Ankara, Turkey. \\ ${ }^{2}$ Independent Researcher, Medical Physiologist, Ankara, Turkey.
}

Correspondence Author: Sidika Bulduk

E-mail: bulduks@gmail.com

Received: $16.08 .2020 \quad$ Accepted: 16.09 .2021

\begin{abstract}
Objective: Hygiene is important as the first line of defence to mitigate the spread of pathogens in people's everyday environments. The objective of the present study was to investigate the hygiene behaviors of Turkish adolescents living in Ankara.

Methods: The participants were 822 boys and 834 girls, in total 1656 Turkish adolescents aged between 12-18 years. We conducted a crosssectional study using a sociodemographic form and the Hygiene Behaviour Inventory (H123) including the questions about personal hygiene habits. Data from the study were evaluated statistically by the chi-square test. Statistical analyses were performed using the SPSS software (version 22.0).

Results: Our results showed that the frequency of washing hands on an average day was significantly higher in girls than boys ( $p<0.001$ ). Besides, handwashing scores were significantly higher in girls after coming home from outside, after touching an animal and before preparing food $(p<0.001)$. $56.5 \%$ of girls usually and $43.1 \%$ of boys occasionally washing their hands after handling raw foods and before handling cooked foods $(p<0.05)$. Girls compared to boys tended to wash their hands for 21 seconds or more $(p<0.001)$. We also found that $87.1 \%$ of boys and $12.9 \%$ of girls preferred to wear the same underclothes two days in a row $(p<0.001)$.
\end{abstract}

Conclusion: Girl adolescents have been found to show more rigorous behavior about hygiene compared to boys.

Keywords: Hygiene behaviour inventory, adolescents, healthcare, hygiene practices

\section{INTRODUCTION}

Hygiene is important as the first line of defence to mitigate the spread of pathogens in people's everyday environments. Access to adequate sanitation infrastructure, including toilets, showers and handwashing facilities, has long been identified as a precursor for hygiene and good health. The word hygiene originates with Hygieia, the Greek goddess of health. According to the World Health Organization (WHO), "Hygiene refers to conditions and practices that help to maintain health and prevent the spread of diseases". Hygienic behavior is the regular practice and behaviors related to the preservation of healthy living. Good hygienic behavior improves the quality of life by preventing the spread of communicable diseases. Hygiene behavior includes hand hygiene, personal grooming, household cleanliness, and food-related hygiene. Hygienic practices have helped prevent and control many infectious diseases in both community and hospital environments. This has reduced morbidity and mortality across the world (1-4).

In chronological terms, adolescence is defined as the age between 10 and 19 years. During this transition period from childhood to adulthood, intense cognitive, emotional, social, physical and hormonal transformations take place. During adolescence, young people are assuming responsibility for their health attitudes and behaviors $(5,6)$.

All over the world, 3.4 million people, mostly children, die annually due to water-related diseases and poor environmental conditions. According to Address Based Population Registration System (ABPRS) results; while Turkey's total population was 80 million 810 thousand and 525 by the end of 2017, child population was 22 million 883 thousand and 288 . While the child population which includes the 0-17 age group according to the definition of the United Nations constituted $48.5 \%$ of the total population in 1970 , this proportion was $41.8 \%$ in 1990 and $28.3 \%$ in 2017 . In Turkey, adolescents are doubled in the absence of proper guidance and care of a responsible adult. Many of them are from rural families who have moved in search of a better quality of life in urban centres only to find opportunities for well-paid jobs. Low levels of education, entrenched social 
attitudes and customs also affect the protective environment for adolescents of both sexes. Therefore, adolescents are a priority group for health promotion, due to the behaviors that expose them to different situations that represent health risks. For the health professionals to emphasize effective intervention measures, they need to get to know the adolescents' health-related knowledge and practices, as their habits interfere directly with their quality of life in adulthood $(7,8)$.

Pengpid and Peltzer (2010) examined the hygiene behavior of 25,760 school children aged $13-15$ years from nine African countries. They reported sub-optimal hygiene behaviors, the proportions of school children reporting optimal (>once a day) tooth brushing (77.3\%), was higher than the proportions reported for washing their hands regularly before meals (62.2\%), after toileting (58.4\%) and washing their hands with soap (35.0\%) (9). Arikan et al. (2014) investigated the personal hygiene status in 1521 primary school students. They found that $27.7 \%$ of students had inadequate personal hygiene. The number of students with poor hygiene increased with the decreasing maternal education level and household income level. Also, the frequency of having poor hygiene was higher among boys (10). The study was aimed to evaluate the hygiene behavior of middle school students in Ankara Turkey.

\section{METHODS}

\subsection{Participants and Setting}

A cross-sectional study was carried out among adolescents from randomly selected, five public middle schools in the capital city of Turkey, Ankara. Data were collected in March 2016. The study population included 1656 adolescents, 822 boys, and 834 girls were selected through simple random sampling. All participants ranged from 12 to14 years ( $B=822,49.7 \%, G=834,50.4 \%$ ). Inclusion criteria were; able to comprehend and communicate using Turkish, having no psychiatric history and being willing to volunteer to complete the questionnaires.

\subsection{Instruments}

The questionnaires were administered to the students during class hours. Researchers explained the nature of the study to all students and showed them how to complete the questionnaires. With the assistance of the teachers, students were invited to participate in the study and asked to fill out the questionnaires as honestly and accurately as possible. Students were assured of the confidentiality of their responses. In the questionnaire, the students were asked about age, gender, sleeping in the separate bedroom and the educational status of their parents. To consider the information on students' hygiene behavior, the hygiene inventory (HI23) was used.

The HI23 tool assists health professionals to assess the necessary practice populations place on themselves in preventing the spread of healthcare-associated infections. The original HI23 was developed by Stevenson et al. (2009) (11). The scale was adapted to Turkish in 2010 by Altun et al. The coefficient alpha was 0.79 for the HI23. The finding indicates that $\mathrm{HI} 23$ is a valid and reliable tool for measuring hygiene management practices in the Turkish population The HI23 comprised 5 sub-scales: general, household, foodrelated, hand-washing technique, and personal hygiene. The HI23 scale consists of 23 items assessed on a 5-point Likert scale. Higher scores indicating more frequent or higher levels of these practices and representing higher hygiene behavior (12).

Questions 2 to 8 and 12 to 16 had common response options: "always" (scored as 4), "usually" (3), "occasionally" (2), and "never" (1). Additional response options were provided for questions 3 ("don't touch them"), 4 ("never eat with hands") and 9 ("never use public toilets"), all scored as 4 (ie, hygiene-related response). Additional response options also were included for questions 5 ("never prepare food"), 6 ("never prepare food"), 12 ("never handle raw food"), 16 ("never handle raw food"), 14 ("don't use them"), and 14 ("unsure"). If an additional response was endorsed, then an average score (ie, 2.5) was given. Question 1 had the following response options: "never" (scored as 1), "1 to 5" (2), "6 to 10 " (3) and "11" (4). For question 8, response options were "less than once a day" (scored as 4), "once a day" (3), "twice a day" (2), and "more than twice a day" (1). For questions 9 to 11 , response options were "never" (scored as 1) "once" (2) "twice" (3) "three times or more" (4), and "unsure." "Unsure" responses were coded with an average score (ie, 2.5). For question 22, the response options were "under 5 seconds" (scored as 1), "6 to 10 seconds" (2), "11 to 20 seconds" (3) and (21 seconds or more" (4). Question 19 had the response options "often" (scored as 4), "sometimes" (3), "rarely" (2), and "never" (1). Finally, questions 20 to 23 had response options "never" (scored as $4)$, "rarely" (3), "sometimes" (2) and "often" (1).

\subsection{Ethical Aspects of the Study}

Students were assured of the confidentiality of their responses. The study was conducted in compliance with the Helsinki Declaration. All the materials used in the study were reviewed and approved by the Executive Boards of the Schools. All data collection protocols and research design were approved by the Ethical Commission of the Gazi University, (18/06/2015-26636).

\subsection{Statistical Analyses}

Statistical analyses were performed with SPSS version 22.0 (Statistical Package for Social Sciences, Chicago, Illinois, United States). Normality was tested using the Shapiro-Wilk test, followed by the chi-square test for comparison between boys and girls. $P$ values $<0.05$ and $<0.001$ were considered statistically significant. 


\section{RESULTS}

The study was carried out on a total of 1656 students consisting of 822 boys (49.7\%) and 834 girls (50.4\%) adolescents (range, 12-14 years). Of the adolescents included in the study, $30.6 \%$ were $12,31.8 \%$ were 13 and $37.5 \%$ were 14 years old.

In Table 1, maternal education levels of adolescents were secondary (25.9\%) and high school (40.3\%). Paternal education levels of adolescents were high school (32.6\%) and university (26.6\%).

According to Table 2, the frequency of washing hands on an average day was significantly higher in girls than boys $(p<0.001)$. In addition, handwashing scores were significantly higher in girls after coming home from outside, after touching an animal and before preparing food $(p<0.001)$. As shown in Table 2, the girls usually preferred to cover the seat of a public toilet with paper $(p<0.001)$.

In the evaluation of food hygiene scores in Table 3, 56.5\% of girls usually and $43.1 \%$ of boys occasionally washing their hands after handling raw foods and before handling cooked foods $(p<0.05)$. There were no significant differences between the scores of boys and girls for washing utensils after handling raw foods and before handling cooked foods. $46.1 \%$ of boys and $31.7 \%$ of girls stated that they could not be sure of the use of separate chopping boards for raw and cooked foods $(p<0.05)$.

Table 4 shows that there was not a significant difference between hand hygiene scores of both sexes. However, the time duration of handwashing (54\% of girls and $11.9 \%$ of boys tended to wash their hands for 21 seconds or more) scores were significantly higher in girls $(p<0.001)$. Also, the habit of using antibacterial gel or wipes scores (while14.9\% of girls and $0.5 \%$ of boys responded "often", 39.8\% of girls and $25.8 \%$ of boys responded "sometimes" to the survey question) were significantly higher in girls $(p<0.05)$.

Table 5 shows that $87.1 \%$ of boys and $12.9 \%$ of girls preferred to wear the same underclothes two days in a row $(p<0.001)$. Parents' educational levels positively influence the hygiene attitude of adolescents.

Table 1. Distribution of demographic characteristics of adolescents ( $n: 1656)$

\begin{tabular}{|c|c|c|c|c|c|c|}
\hline Gender & \multicolumn{3}{|c|}{$n$} & \multicolumn{3}{|c|}{$\%$} \\
\hline Boy & \multicolumn{3}{|c|}{822} & \multicolumn{3}{|c|}{49.7} \\
\hline Girl & \multicolumn{3}{|c|}{834} & \multicolumn{3}{|c|}{50.4} \\
\hline & \multicolumn{2}{|c|}{ Boy $(n: 822)$} & \multicolumn{2}{|c|}{ Girl (n:834) } & \multicolumn{2}{|c|}{ Sum } \\
\hline Age groups & $n$ & $\%$ & $n$ & $\%$ & $n$ & $\%$ \\
\hline 12 & 223 & 27.1 & 284 & 34.1 & 507 & 30.6 \\
\hline 13 & 271 & 33.0 & 257 & 30.9 & 528 & 31.8 \\
\hline 14 & 328 & 39.9 & 293 & 35.0 & 621 & 37.5 \\
\hline \multicolumn{7}{|c|}{ Maternal Education } \\
\hline Primary & 92 & 11.2 & 104 & 12.5 & 196 & 11.8 \\
\hline Secondary & 231 & 28.1 & 198 & 23.7 & 429 & 25.9 \\
\hline High School & 321 & 39.1 & 346 & 41.5 & 667 & 40.3 \\
\hline University & 178 & 21.7 & 186 & 22.3 & 364 & 22.8 \\
\hline \multicolumn{7}{|c|}{ Paternal Education } \\
\hline Primary & 77 & 9.4 & 93 & 11.2 & 170 & 10.2 \\
\hline Secondary & 305 & 37.0 & 201 & 24.1 & 506 & 30.6 \\
\hline High School & 238 & 29.0 & 302 & 36.2 & 540 & 32.6 \\
\hline University & 202 & 24.6 & 238 & 28.5 & 440 & 26.6 \\
\hline
\end{tabular}


Table 2. General Hygiene Behaviours of the Adolescents According to H123 Scale (Boy: 822; Girl:834) n: 1656

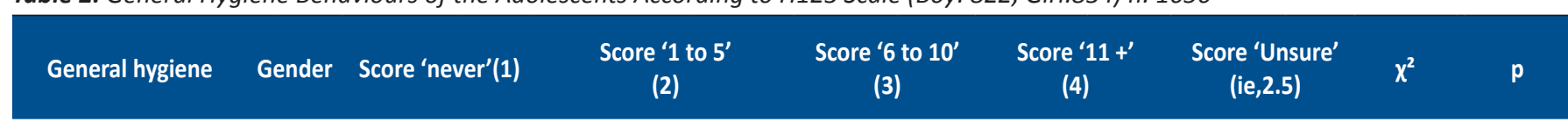

\begin{tabular}{|c|c|c|c|c|c|c|c|c|c|c|c|c|c|}
\hline Questions & & $\mathbf{n}$ & $\%$ & n & $\%$ & $n$ & $\%$ & $\mathbf{n}$ & $\%$ & $n$ & $\%$ & & \\
\hline $\begin{array}{l}\text { 1. On an average day, } \\
\text { approximately how } \\
\text { many times do you } \\
\text { wash your } \\
\text { hands? }\end{array}$ & G & $\begin{array}{c}- \\
- \\
\text { Score } \\
\text { 'never'(1) }\end{array}$ & - & $\begin{array}{c}96 \\
57 \\
\text { Score } \\
\text { 'occasionally' } \\
\text { (2) }\end{array}$ & 11.7 & $\begin{array}{c}214 \\
394 \\
\text { Score } \\
\text { 'usually' } \\
\text { (3) }\end{array}$ & 26.0 & $\begin{array}{c}271 \\
301 \\
\text { Score } \\
\text { 'always' } \\
\text { (4) }\end{array}$ & 33.0 & $\begin{array}{c}24 \\
82 \\
\text { Score } \\
\text { 'unsure' } \\
\text { (ie2.5) }\end{array}$ & 3.3 & 20.614 & $<0.001 * *$ \\
\hline $\begin{array}{l}\text { 2. Upon getting } \\
\text { home, do you wash } \\
\text { your hands? }\end{array}$ & $B$ & 17 & 2.0 & 107 & $\begin{array}{l}13.1 \\
10.1\end{array}$ & 288 & 35.0 & 199 & 24.2 & 211 & $\begin{array}{l}25.7 \\
11.5\end{array}$ & 32.233 & $<0.001 * *$ \\
\hline $\begin{array}{l}\text { 3. After touching a } \\
\text { pet or other animal, } \\
\text { do you wash your } \\
\text { hands? }\end{array}$ & B & 8 & 1.0 & 279 & 33.9 & 361 & 43.9 & 144 & 17.5 & 30 & $\begin{array}{l}3.7 \\
2.1\end{array}$ & 47.066 & $<0.001^{* *}$ \\
\hline $\begin{array}{l}\text { 4. Before eating food } \\
\text { with your hands, } \\
\text { do you wash your } \\
\text { hands? }\end{array}$ & $B$ & 12 & 1.5 & 296 & 30.0 & 182 & 22.1 & 278 & 33.8 & 54 & $\begin{array}{l}6.6 \\
9.2\end{array}$ & 49.211 & 0.039* \\
\hline $\begin{array}{l}\text { 5. Before preparing } \\
\text { food, do you wash } \\
\text { your hands? }\end{array}$ & B & - & - & 128 & 13.5 & 410 & 49.9 & 271 & 33.0 & 30 & $\begin{array}{l}3.6 \\
2.5\end{array}$ & 5.477 & 0.341 \\
\hline $\begin{array}{l}\text { 6. If you need to } \\
\text { touch your face or } \\
\text { body (eg, to scratch) } \\
\text { while preparing food, } \\
\text { do you wash your } \\
\text { hands? }\end{array}$ & B & 482 & 58.6 & 216 & 26.3 & 92 & 11.2 & - & 0.1 & 32 & 3.9 & 6.801 & 0.257 \\
\hline $\begin{array}{l}\text { 7. Do you wash } \\
\text { fruit and vegetables } \\
\text { before you eat them? }\end{array}$ & B & 138 & 16.5 & 216 & 48.8 & 164 & 20.0 & 160 & 19.2 & 232 & $\begin{array}{l}28.2 \\
4.7\end{array}$ & 15.021 & $0.004 * *$ \\
\hline $\begin{array}{l}\text { 8. When you use a } \\
\text { public toilet, do you } \\
\text { cover the seat with } \\
\text { paper? }\end{array}$ & $B$ & 617 & 75.1 & 332 & 39.8 & 127 & 15.2 & 155 & 18.6 & 166 & 20.1 & 71.119 & $<0.001^{* *}$ \\
\hline
\end{tabular}

$(p<0.05)^{*},(p<0.001)^{* *}$ 
Table 3. Household Hygiene and Food-Related Hygiene Behaviours of the Adolescents According to H123 Scale (Boy: 822; Girl:834) n: 1656

\begin{tabular}{|c|c|c|c|c|c|c|c|c|c|c|c|c|c|}
\hline \multirow[t]{2}{*}{$\begin{array}{l}\text { Household hygiene } \\
\text { Questions }\end{array}$} & \multirow[t]{2}{*}{ Gender } & \multicolumn{2}{|c|}{$\begin{array}{c}\text { Score } \\
\text { 'never'(1) }\end{array}$} & \multicolumn{2}{|c|}{$\begin{array}{c}\text { Score } \\
\text { 'once'(2) }\end{array}$} & \multicolumn{2}{|c|}{ Score 'twice'(3) } & \multicolumn{2}{|c|}{$\begin{array}{c}\text { Score } \\
\text { 'three times or } \\
\text { more' (4) }\end{array}$} & \multicolumn{2}{|c|}{$\begin{array}{c}\text { Score } \\
\text { 'unsure'(ie2.5) }\end{array}$} & \multirow[t]{2}{*}{$x^{2}$} & \multirow[t]{2}{*}{$p$} \\
\hline & & $\mathrm{n}$ & $\%$ & $S$ & $\%$ & $S$ & $\%$ & $S$ & $\%$ & $S$ & $\%$ & & \\
\hline $\begin{array}{l}\text { 9. How often, in the last month, has } \\
\text { your } \\
\text { bathroom at home been cleaned? }\end{array}$ & $\begin{array}{l}B \\
G\end{array}$ & $\begin{array}{l}17 \\
-\end{array}$ & $\begin{array}{l}2.1 \\
-\end{array}$ & $\begin{array}{l}419 \\
107\end{array}$ & $\begin{array}{l}51.0 \\
12.8\end{array}$ & $\begin{array}{r}29 \\
441\end{array}$ & $\begin{array}{r}3.5 \\
52.9\end{array}$ & - & $\begin{array}{l}- \\
1.1\end{array}$ & $\begin{array}{l}357 \\
277\end{array}$ & $\begin{array}{l}43.4 \\
33.2\end{array}$ & 52.496 & $0.029 *$ \\
\hline $\begin{array}{l}\text { 10. How often, in the last month, } \\
\text { has } \\
\text { your toilet at home been cleaned? }\end{array}$ & B & 3 & $\begin{array}{c}0.4 \\
-\end{array}$ & $\begin{array}{c}442 \\
17\end{array}$ & $\begin{array}{c}53.8 \\
2.3\end{array}$ & $\begin{array}{l}218 \\
436\end{array}$ & $\begin{array}{l}26.5 \\
52.2\end{array}$ & $\begin{array}{c}6 \\
296\end{array}$ & $\begin{array}{l}0.7 \\
35.4\end{array}$ & $\begin{array}{l}153 \\
85\end{array}$ & $\begin{array}{l}18.6 \\
10.1\end{array}$ & 47.124 & $0.024 *$ \\
\hline $\begin{array}{l}\text { 11. How often, in the last month, } \\
\text { has } \\
\text { your kitchen at home been cleaned? }\end{array}$ & $\begin{array}{l}\text { B } \\
\text { G }\end{array}$ & $\begin{array}{l}11 \\
3\end{array}$ & $\begin{array}{l}1.4 \\
0.4\end{array}$ & $\begin{array}{l}408 \\
151\end{array}$ & $\begin{array}{l}49.6 \\
18.1\end{array}$ & $\begin{array}{l}218 \\
505\end{array}$ & $\begin{array}{l}26.5 \\
60.6\end{array}$ & $\begin{array}{r}66 \\
169\end{array}$ & $\begin{array}{l}8.0 \\
20.2\end{array}$ & $\begin{array}{c}119 \\
6\end{array}$ & $\begin{array}{l}14.5 \\
0.7\end{array}$ & 23.931 & $0.031 *$ \\
\hline
\end{tabular}

Food-related hygiene

Questions score 'never' score 'occasionally score 'usually'

(1) (2) (3) score 'always'

(5)
(6)

\begin{tabular}{|c|c|c|c|c|c|c|c|c|c|c|c|c|c|}
\hline & & II & 70 & $\pi$ & 10 & $n$ & 70 & $n$ & 70 & $\pi$ & 70 & $x$ & $p$ \\
\hline \multirow{2}{*}{$\begin{array}{l}\text { 12. After handling raw foods and } \\
\text { before } \\
\text { handling cooked foods, do you } \\
\text { wash your hands? }\end{array}$} & B & 245 & 29.8 & 354 & 43.1 & 73 & 8.9 & 29 & 3.5 & 121 & 14.7 & 38.516 & $<0.001^{* *}$ \\
\hline & G & 24 & 2.9 & 162 & 19.4 & 471 & 56.5 & 112 & 13.4 & 65 & 7.8 & & \\
\hline \multirow{2}{*}{$\begin{array}{l}\text { 13. After handling raw foods and } \\
\text { before handling cooked foods, do } \\
\text { you wash the utensils used? }\end{array}$} & B & 314 & 38.2 & 108 & 13.1 & 226 & 27.5 & 11 & 1.4 & 163 & 19.8 & 7.769 & 0.517 \\
\hline & G & 296 & 35.5 & 118 & 14.1 & 299 & 35.9 & 22 & 2.6 & 99 & 11.9 & & \\
\hline \multirow{2}{*}{$\begin{array}{l}\text { 14. Do you use separate chopping } \\
\text { boards for raw and cooked foods? }\end{array}$} & B & 416 & 50.6 & 18 & 2.2 & 9 & 1.1 & - & - & 379 & 46.1 & 51.916 & $0.032 *$ \\
\hline & G & 531 & 63.7 & 32 & 3.8 & 7 & 0.8 & - & - & 264 & 31.7 & & \\
\hline
\end{tabular}

$(p<0.05)^{*},(p<0.001)^{* *}$

Table 4. Hand Hygiene Behaviours of the Adolescents According to H123 Scale (Boy: 822; Girl:834) n: 1656

\begin{tabular}{|c|c|c|c|c|c|c|c|c|c|c|c|c|c|}
\hline \multirow{2}{*}{$\begin{array}{l}\text { Hand hygiene technique } \\
\text { Questions }\end{array}$} & \multirow[t]{2}{*}{ Gender } & \multicolumn{2}{|c|}{$\begin{array}{c}\text { Score } \\
\text { 'never'(1) }\end{array}$} & \multicolumn{2}{|c|}{$\begin{array}{c}\text { Score } \\
\text { 'occasionally'(2) }\end{array}$} & \multicolumn{2}{|c|}{$\begin{array}{c}\text { Score } \\
\text { 'usually'(3) }\end{array}$} & \multicolumn{2}{|c|}{$\begin{array}{c}\text { Score } \\
\text { 'always'(4) }\end{array}$} & \multirow{2}{*}{$\begin{array}{l}\text { Score } \\
\text { 'unsure' } \\
\text { (ie 2.5) } \\
\quad \mathrm{n}\end{array}$} & \multirow[b]{2}{*}{$\%$} & \multirow[t]{2}{*}{$x^{2}$} & \multirow[t]{2}{*}{ p } \\
\hline & & $n$ & $\%$ & $n$ & $\%$ & $\mathrm{n}$ & $\%$ & $\mathrm{n}$ & $\%$ & & & & \\
\hline \multirow{2}{*}{$\begin{array}{l}\text { 15. When warm water is available, do you } \\
\text { wash your hands with warm water? }\end{array}$} & B & 2 & 0.2 & 129 & 15.7 & 191 & 23.2 & 294 & 35.8 & 206 & 25.1 & 8.891 & 0.254 \\
\hline & G & - & - & 131 & 15.7 & 193 & 23.1 & 309 & 37.1 & 201 & 24.1 & & \\
\hline \multirow{2}{*}{$\begin{array}{l}\text { 16. After washing your hands, do you dry } \\
\text { your hands completely? }\end{array}$} & B & - & - & 241 & 29.3 & 319 & 38.8 & 164 & 20.0 & 98 & 11.9 & 9.414 & 0.261 \\
\hline & G & - & - & 218 & 26.1 & 331 & 39.7 & 184 & 22.1 & 101 & 12.1 & & \\
\hline \multirow{4}{*}{$\begin{array}{l}\text { 17. When soap is available, do you wash } \\
\text { your hands with soap? }\end{array}$} & B & - & - & - & - & 341 & 41.5 & 468 & 56.9 & 13 & 1.6 & 4.716 & 0.672 \\
\hline & G & - & - & - & - & 319 & 38.2 & 491 & 58.9 & 24 & 2.9 & & \\
\hline & & \multicolumn{2}{|c|}{$\begin{array}{l}\text { 'under } 5 \\
\text { seconds' } \\
\text { Score (1) }\end{array}$} & \multicolumn{2}{|c|}{$\begin{array}{l}\text { '6 to10 seconds' } \\
\text { Score (2) }\end{array}$} & \multicolumn{2}{|c|}{$\begin{array}{l}\text { '11 to } 20 \\
\text { seconds' } \\
\text { Score (3) }\end{array}$} & \multicolumn{2}{|c|}{$\begin{array}{l}\text { '21 seconds } \\
\text { or more' } \\
\text { Score (4) }\end{array}$} & & & & \\
\hline & & $S$ & $\%$ & $S$ & $\%$ & $S$ & $\%$ & $S$ & $\%$ & & & & \\
\hline \multirow{4}{*}{$\begin{array}{l}\text { 18. When you wash your hands, } \\
\text { approximately how long do you wash them } \\
\text { for? }\end{array}$} & B & 26 & 3.2 & 327 & 39.8 & 371 & 45.1 & 98 & 11.9 & & & 40.319 & $<0.001^{* *}$ \\
\hline & G & 3 & 0.3 & 172 & 20.6 & 209 & 25.1 & 450 & 54.0 & & & & \\
\hline & & \multicolumn{2}{|c|}{$\begin{array}{c}\text { 'Often' } \\
\text { Score (4) }\end{array}$} & \multicolumn{2}{|c|}{$\begin{array}{l}\text { 'Sometimes' } \\
\text { Score (3) }\end{array}$} & \multicolumn{2}{|c|}{$\begin{array}{l}\text { 'Rarely' } \\
\text { Score (2) }\end{array}$} & \multicolumn{2}{|c|}{$\begin{array}{l}\text { 'Never' } \\
\text { Score (1) }\end{array}$} & & & & \\
\hline & & $S$ & $\%$ & $S$ & $\%$ & $S$ & $\%$ & $S$ & $\%$ & & & & \\
\hline \multirow{2}{*}{$\begin{array}{l}\text { 19. Do you use antibacterial gel or wipes to } \\
\text { clean your hands? }\end{array}$} & B & 4 & 0.5 & 77 & 9.4 & 212 & 25.8 & 84 & 10.2 & & & 48.412 & $0.041^{*}$ \\
\hline & G & 124 & 14.9 & 332 & 39.8 & 324 & 38.8 & 54 & 6.5 & & & & \\
\hline
\end{tabular}

$(p<0.05)^{*},(p<0.001)^{* *}$ 
Table 5. Personal Hygiene Behaviours of the Adolescents According to H123 Scale (Boy: 822; Girl:834) n: 1656

\begin{tabular}{|c|c|c|c|c|c|c|c|c|c|c|c|}
\hline \multirow{2}{*}{$\begin{array}{l}\text { Personal hygiene } \\
\text { Questions }\end{array}$} & \multirow[t]{2}{*}{ Gender } & \multicolumn{2}{|c|}{$\begin{array}{c}\text { Score } \\
\text { 'Never'(4) }\end{array}$} & \multicolumn{2}{|c|}{$\begin{array}{c}\text { Score } \\
\text { 'Rarely'(3) }\end{array}$} & \multicolumn{2}{|c|}{$\begin{array}{c}\text { Score } \\
\text { 'Sometimes'(2) }\end{array}$} & \multicolumn{2}{|c|}{$\begin{array}{c}\text { Score } \\
\text { 'Often'(1) }\end{array}$} & \multirow[t]{2}{*}{$x^{2}$} & \multirow[t]{2}{*}{$p$} \\
\hline & & $S$ & $\%$ & $S$ & $\%$ & $\mathbf{S}$ & $\%$ & S & $\%$ & & \\
\hline \multirow{2}{*}{$\begin{array}{l}\text { 20. Do you wear the same top or shirt } \\
\text { two days in a row? }\end{array}$} & B & 1 & 0.1 & 22 & 2.7 & 158 & 19.2 & 641 & 78.0 & \multirow{2}{*}{4.578} & \multirow{2}{*}{0.252} \\
\hline & $\mathrm{G}$ & - & - & 29 & 3.5 & 123 & 14.7 & 682 & 81.8 & & \\
\hline \multirow{2}{*}{$\begin{array}{l}\text { 21. Do you wear the same skirt or pants } \\
\text { two days in a row? }\end{array}$} & B & - & - & - & - & 9 & 1.1 & 813 & 98.9 & \multirow{2}{*}{4.680} & \multirow{2}{*}{0.294} \\
\hline & $\mathrm{G}$ & - & - & 2 & 0.2 & 9 & 1.1 & 823 & 98.7 & & \\
\hline \multirow{2}{*}{$\begin{array}{l}\text { 22. Do you wear the same underclothes } \\
\text { two days in a row? }\end{array}$} & B & 18 & 2.2 & 69 & 8.4 & 19 & 2.3 & 716 & 87.1 & \multirow{2}{*}{21.490} & \multirow{2}{*}{$<0.001 * *$} \\
\hline & G & 147 & 17.6 & 23 & 2.8 & 556 & 66.7 & 108 & 12.9 & & \\
\hline \multirow{2}{*}{$\begin{array}{l}\text { 23. Do you go without a wash, shower } \\
\text { or bath two days in a row? }\end{array}$} & B & - & - & 167 & 20.3 & 642 & 78.1 & 13 & 1.6 & \multirow{2}{*}{6.741} & \multirow{2}{*}{0.266} \\
\hline & G & 1 & 0.1 & 146 & 17.5 & 669 & 80.2 & 18 & 2.2 & & \\
\hline
\end{tabular}

$(p<0.05)^{*},(p<0.001)^{* *}$

\section{DISCUSSION}

Hygiene is generally discussed in the context of preventing the transmission of infection. Hygiene behavior is the regular practices and behaviors associated with the preservation of healthy living $(13,14)$. An estimated one million annual infectious diseases worldwide could be averted by improved hygiene practices (15). Adolescence represents a period of transition when children are establishing autonomy over their behaviors (16). Additionally, it is a stage when teens do not always appreciate help from adults, despite the strong influence of the family on hygiene issues (17). In 2011, Miko et al. examined personal and household hygiene among 299 undergraduate college students In New York. They found that girls noted better personal hygiene than boys (18). Kaya et al. (2006), planned to determine the personal hygiene behaviors of 236 secondary and high students in Ankara. They stated that the average hygiene score of boys was lower than girls (19). Another study among 146,462 middle school students who participated in the Global School-based Student Health Survey from 44 low and middle-income countries presented some differences between the genders (20). According to this study, girls took sufficiently care on their bathing, washing, and tooth brushing. Dorri et al. (2009) investigated the relationship between oral hygiene behaviors and general hygiene behaviors among 1054 Iranian adolescents living in Mashhad. The results showed that girls were significantly more likely than boys to practice oral hygiene and general hygiene behaviors (21). Consistent with previous researches, in our study, we found that most of the hygiene scores of the girls were significantly higher than the boys. It can be said that girl adolescents have been found to show more rigorous behavior about hygiene compared to boys. Possible factors associated with sex differences in hygienic behaviors. For example, the traditional social role may also have a role in influencing hygiene behaviors. Women and girls are often regarded as primary care providers in a family. Also, girls' higher compliance is associated with their tendency to practice socially acceptable behaviors.
Health promotion has been defined as the process of enabling people to increase control over and improve their health. One of the intervention strategies in health promotion is health education. The earliest critical period is believed to be the transition from primary to secondary school. It has been shown that relatively stable patterns of health-related behaviors are established during adolescence (22). Kim et al. (2012) studied to determine the effects of educational intervention on 400 adolescents' hand hygiene behavior. They showed a significant increase in proper handwashing and food safety knowledge after education. Education is very important in raising awareness about hygiene behavior in adolescents (23). Zhou et al. (2015) examined the effectiveness of a self-regulation intervention among 307 Chinese adolescents to identify the effects of planning on hand hygiene. They demonstrated that teaching planning strategies constituted an approach to improve regular hand hygiene practice in adolescents (24).

Some limitations should be taken into account in interpreting our results. Firstly, the self-reported nature of all outcomes means that our data may be influenced by this technique. Secondly, this study did not include an evaluation of lifestyle factors such as smoking, alcohol consumption, eating habits, stressful situations at home.

\section{CONCLUSION}

In conclusion, our findings reinforce previous studies reported about the hygiene behavior of adolescents, we also illuminate certain subpopulations of middle school students who may benefit from targeted health education. Based on our data, hygiene-promoting programs can be effective for improving hygiene practices and the motivation of adolescents. Visual prompts in addition to educational campaigns may promote better hygienic behavior among adolescents. Besides, expanding the number of participants and applying other analysis techniques can contribute to enhance the range of the results and reduce the study limitations. 


\section{Acknowledgments}

This research received no specific grant from any funding agency in the public, commercial, or not-for-profit sectors. The authors would like to thank the adolescents who participated in this study.

\section{REFERENCES}

[1] Aunger R, Greenland K, Ploubidis G, Schmidt W, Oxford J, Curtis V. The Determinants of Reported Personal and Household Hygiene Behaviour: A Multi-Country Study. Plos One 2016; 11(8): ARTN e0159551.

[2] Leibler JH, Nguyen DD, León C, Gaeta JM, Perez D. Personal Hygiene Practices among Urban Homeless Persons in Boston, MA. International Journal of Environmental Research and Public Health 2017; 14(8): 928.

[3] Vandegrift R, Bateman AC, Siemens KN, Nguyen M, Green JL, Van Den Wymelenberg KG. Cleanliness in context: reconciling hygiene with a modern microbial perspective. Microbiome 2017; 5(1):76.

[4] WHO. WHO guidelines on hand hygiene in health care: first global patient safety challenge. Geneva: 2009. W. H. Organization. Retrieved from https://www.who.int/ gpsc/5may/tools/978.924.1597906/en/

[5] Kendre VV, Ghattergi CH. A Study on menstruation and personal hygiene among adolescent girls of Government Medical College, Solapur. Natl J Community Med 2013; 4(2): 272-276.

[6] Sousa ZAA, Silva JG, Ferreira MA. Knowledge and Practices of Teenagers about Health: Implications for the Lifestyle and Self Care. Escola Anna Nery 2014; 18: 400-406.

[7] WHO. Water, sanitation, and hygiene in health care facilities: status in low - and middle-income countries and way forward. Geneva: 2015. W. H. Organization. Retrieved from https:// www.who.int/water_sanitation_health/publications/washhealth-care-facilities/en/

[8] TurkStat. Statistics on Child. Ankara: Turkish Statistical Institute. 2017. Retrieved from http://www.turkstat.gov.tr/ HbPrint.do?id=24645.

[9] Peltzer K, Pengpid S. Oral and hand hygiene behaviour and risk factors among in-school adolescents in four southeast Asian countries. Int. J. Environ. Res. Public Health 2014; 11: 27802792.

[10] Arikan I, Dibeklioglu SE, Arik O, Gulcan A. Personal hygiene status among primary school students in an urban area in the west of Turkey. American Journal of Research Communication 2014; 2(7): 23-36.
[11] Stevenson RJ, Case TI, Hodgson D, Porzig-Drummond R, Barouei J, Oaten MJ. A scale for measuring hygiene behavior: development, reliability, and validity. Am J Infect Control, 2009; 37(7): 557-564.

[12] Altun I, Cinar ND, Dede C. Psychometric properties of the hygiene inventory in a Turkish population. Health Med 2010; 4(4):1009-19.

[13] Nicolle L. Hygiene: what and why?. CMAJ 2007; 176: 767-768.

[14] Newson RS, Lion R, Crawford RJ, Curtis V, Elmadfa I, Feunekes GI. Behaviour change for better health: nutrition, hygiene, and sustainability. BMC Public Health 2013; 13 Suppl 1: S1.

[15] Ranasinghe S, Ramesh S, Jacobsen KH. Hygiene and mental health among middle school students in India and 11 other countries, Journal of Infection and Public Health, 2016; 9(4): 429-435.

[16] Hall-Scullin E, Goldthorpe J, Milsom K, Tickle M. A qualitative study of the views of adolescents on their caries risk and prevention behaviours. BMC Oral Health 2015; 15: 141.

[17] Bombert F, Manso AC, Sousa Ferreira C, Nogueira P, Nunes C. Sociodemographic factors associated with oral health in 12-year-old adolescents: hygiene behaviours and health appointments. A cross-sectional national study in Portugal. Int Dent J 2018; 68: 327-335.

[18] Miko BA, Cohen B, Conway L, Gilman A, Seward SL, Larson E. Determinants of personal and household hygiene among college students in New York City, 2011. American journal of infection control 2012; 40(10): 940-5.

[19] Kaya $M$, Büyükserbetci $M$, Meric $M B$, Çelebi $A E$, Boybeyi $O$. Ankara'da Bir Lisenin 9 ve 10. Sınıf Öğrencilerinin Kişisel Hijyen Konusunda Davranışlarının Belirlenmesi. Sted 2006; 15(10): 179-183.

[20] McKittrick TR, Jacobsen KH. Oral hygiene practices among middle-school students in 44 low- and middle-income countries. Int Dent J 2014; 64:164-170.

[21] Dorri M, Sheiham A, Watt RG. Relationship between general hygiene behaviours and oral hygiene behaviours in Iranian adolescents. Eur J Oral Sci 2009;117: 407-412.

[22] Brukiene V, Aleksejūnienè J. An overview of oral health promotion in adolescents. Int J Paediatr Dent 2008; 9(3):16371.

[23] Kim EJ, Pai A J, Kang NE, Kim WK, Kim YS, Moon HK. The effects of food safety education on adolescents' hand hygiene behavior: an analysis of stages of change. Nutrition Research and Practice 2012;6(2):169-74.

[24] Zhou G, Jiang T, Knoll N, Schwarzer R. Improving hand hygiene behaviour among adolescents by a planning intervention. Psychol Health Med 2015;20(7):824-831. 